\title{
Analysis of the evolution of the residual risk of HIV transmission at the National Blood Transfusion Center (CNTS) of Lomé (Togo) from January 2008 to December 2012
}

\author{
Liza Koboyo Nadjir, Akuété Yvon Segbena, Jean-Pierre Cazenave
}

\section{ABSTRACT}

Aims:

This study aimed to:

- Analyze the HIV residual risk of transfusion at the CNTS of Lomé from January 2008 to December 2012

- Indicate future directions to strengthen blood safety.

Methods:

The residual risk of HIV transmission by blood transfusion has been estimated by the indirect method proposed by SCHREIBER. This method estimates the risk that a donation was made during the immunologically silent period. Using the incident cases, we calculated the incidence rates of HIV that multiplied by the duration of the serological window period gave the residual risk of transmission.

Results:

Blood donors included in study were a total of 16 , 042 over the five years. Males accounted for 79 . $37 \%$ and $64.41 \%$ of donors were under 30 years. The number of cases of confirmed HIV was zero in 2008, five in 2009, five in 2010, three in 2011, two in 2012. The residual risk ( $R R)$ was respectively $1 / 17391$ in $2009,1 / 19342$ in $2010,1 / 43478$ in 2011 and $1 / 181818$ in 2012. From 2009 to 2012,

Liza Koboyo Nadjir ${ }^{1}$, Akuété Yvon Segbena ${ }^{2}$, Jean-Pierre Cazenave $^{3}$

Affiliations: ${ }^{1}$ CNTS of Lomé, Lomé, Togo; ${ }^{2}$ Department of Laboratories, Campus Teaching Hospital of Lomé, Lomé, Togo; ${ }^{3}$ EFS-Alsace, Strasbourg, France.

Corresponding Author: NADJIR Liza Koboyo Lomé, Togo, BP: 4090; Ph: 00228922337 77; Email: lizanadjir@yahoo. $\mathrm{fr}$

Received: 05 August 2015

Accepted: 17 September 2015

Published: 16 December 2015 the RR decreased by 10.45 times. Conclusion: The residual risk was relatively high in 2009 but has gradually declined over ten times in 2012. A policy of blood donators and the orientation of the CNTS towards new technologies such as the inactivation of the pathogens might contribute to reduce appreciably the $R R$ of diseases transmitted by the blood.

Keywords: Blood donors, residual risk, HIV, CNTS-Lomé

\section{How to cite this article}

Nadjir LK, Segbena AY, Cazenave JP. Analysis of the evolution of the residual risk of HIV transmission at the National Blood Transfusion Center (CNTS) of Lomé (Togo) from January 2008 to December 2012 Int J Blood Transfus Immunohematol 2015;5:29-34.

Article ID: 100020IJBTINK2015

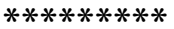

doi:10.5348/ijbti-2015-20-ED-6

\section{INTRODUCTION}

Blood transfusion is one of the ways of transmission of viral pathogens including HIV responsible of the acquired immunodeficiency syndrome (AIDS) [1]. Chronicity, potential complications and difficulties in the management of this disease make it a particularly critical issue for transfusion especially in sub-Saharan Africa (where TOGO is located) where its prevalence is enough high $[1,2]$. The latest estimates of the epidemic shows that HIV prevalence in Togo was 3.4\% in 2010 [3]. To ensure 
blood safety at the CNTS of Lomé, a serological test of HIV is done on donations (after a rigorous selection during medical interviews of donors), making the transmission of HIV exceptional, but not nil. There is indeed a risk of transmission (residual risk) of HIV linked to the "window period" which is the incubation period during which the virus is undetectable in recently infected persons by serological tests tools.

In France the residual risk (RR) of HIV is very low, whereas it is very high in the countries of West Africa whose TOGO (it is 91 times higher in Senegal than France in 2003-2005 [4]. Indeed in TOGO efforts are made to improve blood safety. Hence the importance of our work which aims is to analyze the evolution of the HIV RR in transfusion at the CNTS of Lomé from January 2008 to December 2012.

\section{MATERIALS AND METHODS}

It is a retrospective cross-sectional study in donors of whole blood, volunteers and regular at CNTS, which have done at least two donations for which serologic tests for HIV, hepatitis B and hepatitis C, were negatives during the last donation, between 1 January 2008 and 31 December 2012.

\section{Selection of donors}

The selection of donors was clinical and biological and was based on the eligibility criteria, according to blood safety rules.

Clinical selection of donors: Donors able to donate blood were 18 years old at least and not more than 60 years, weighing more than $50 \mathrm{~kg}$, in apparent good health and having no contraindication to donate blood. The donors had to answer questions about their sexual habits.

Biological selection of donors: It is made after the biological qualification (screening) of blood in a first step at the CNTS. In a second step, all donors blood positive for HIV in CNTS are referred to the National Institute of Hygiene (INH) of Lomé for confirmation of results. Only positive cases at CNTS and INH are declared definitively positive.

Infection Screening in HIV CNTS: HIV screen was done during our study period with two reagent kits: either «Genscreen ULTRA HIV Ag-ABß» BIORAD or "VIRONOSTIKA $®$ HIV Uni-Form II plus O" BIOMERIEUX, depending on the availability of reagents. The validation of the HIV serology results at CNTS was made in accordance with the manufacturer's validation criteria.

Confirmation of infection with HIV INH: The confirmation of HIV infection was made at INH according to the National HIV testing algorithm (Figure 1) [5]. Reagent kits used were: VIRONOSTIKA $®$ HIV Uni-Form II plus O from BIOMERIEUX for test 1, Determine HIV$1 / 2^{\mathrm{TM}}$ from ABBOTT for test 2 and HIV TRI-DOT $®$ for test 3 .

\section{Study Material}

The equipment used had included: CNTS computerized database on donors and their donations, and the HIV status registers of INH.

\section{Study Method}

Procedure of data collection: All information about donors including: the date of donations, age, sex, occupation and HIV serology were collected from the blood bank management and transfusion monitoring computer software "Transfuse CONTROL" used by the CNTS and HIV status registers of INH. These information were then rated on cards assigned to each donor.

Evaluation method of residual risk [2, 4]: The residual risk was assessed using the indirect method proposed by SCHREIBER, measuring on one hand the incidence rate of infection in the population of blood donors while taking into account on the other hand the duration of the "window period".

SCHREIBER equation [4]:

$$
\mathrm{RR}=\frac{\text { Incidence rate } \times \text { duration of the window period } 365}{365}
$$
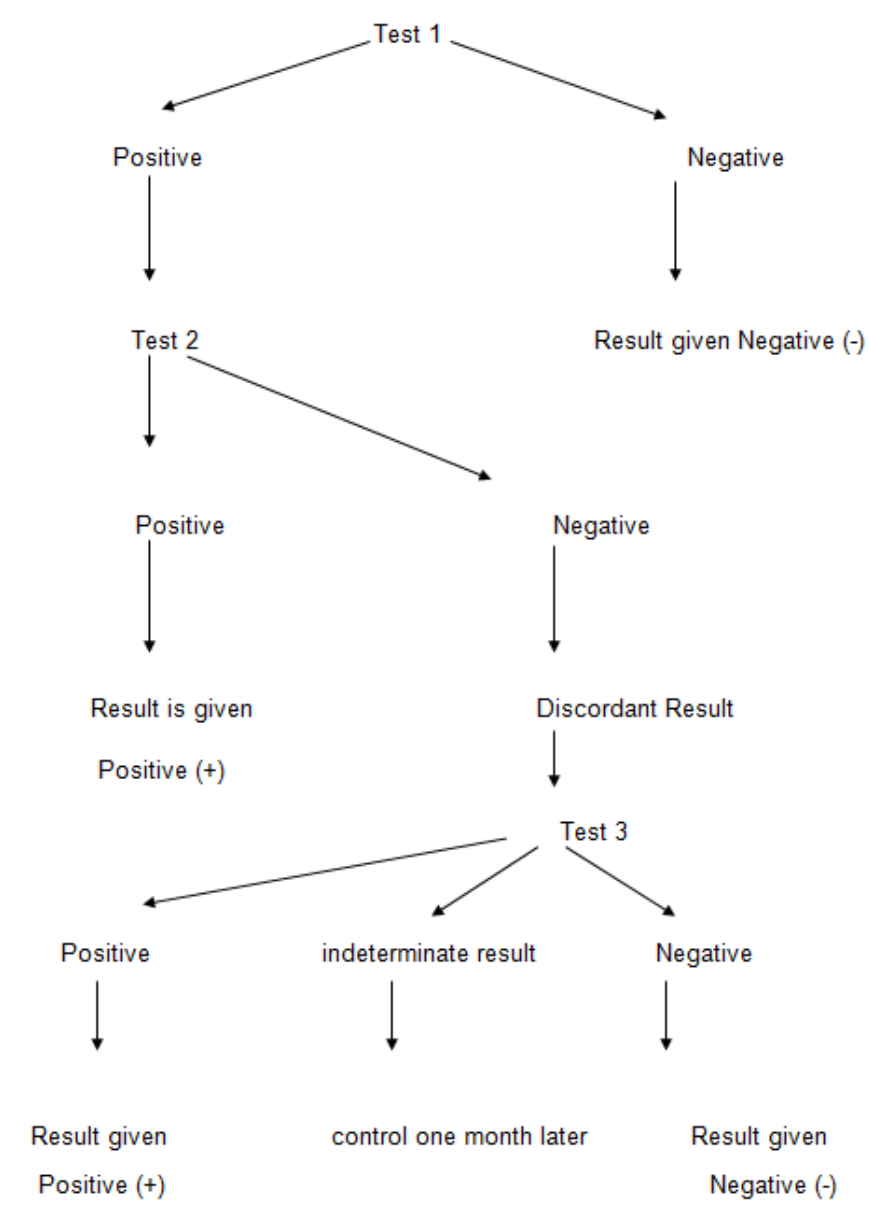

Result given Negative (-)

Figure 1: Screening protocol for HIV infection at INH of Lomé (National HIV testing algorithm). 
The duration of the "silent window" was obtained from the literature: Twenty-two (22) days for HIV [6].

The incidence rate was calculated from regular donors by comparing the number of incident cases per year divided by the number of person-years during the period of five years. Incident cases correspond to the number of cases of seroconversion, that is to say, the number of donors who, during the period of the five-year, have completed at least one negative donation followed by a donation confirmed HIV positive.

The number of person-year was calculated as the sum of the intervals in days between the first and the last donation made by all donors divided by 365 . The incidence rate was then attached to one million personsyears by a rule of three.

Data analysis: Our data were processed by EXCEL 2007. Statistical analysis was performed using Epi Info 3.5 software.

\section{RESULTS}

\section{Socio-demographic parameters}

These parameters were consigned in Table 1 :

The study of the blood donor's distribution by age has shown that donors under 30 years accounted for $64.41 \%$ during these five years. The blood donors over 50 years accounted for only $3.73 \%$.

The distribution of donors according to their professions showed that more than half of the donors were students or apprentices, or a percentage of $55.82 \%$. Private and public sector workers accounted for $40.53 \%$.

\section{Evaluation of residual risk}

Incidence rate per 100,000 person-years Incidence rate can be seen in Table 2.

All the positive cases of HIV were confirmed VIH1. Incidence rate were decreased from 95,46 for 100,000 person-years in 2009 to 09, 11 for 100,000 person-years in 2012.

Evaluation of HIV residual risk of transfusion from January 2008 to December 2012 HIV residual risk is in Table 3.

The residual risk of HIV decreased progressively from1/17391 in 2009 to 1/181818 in 2012.

\section{DISCUSSION}

This study reports data of the evaluation of HIV transfusion RR in CNTS of Lomé from 2008 to 2012. The RR was relatively high but had gradually declined over ten times during the five years.

Donors who participated to the study were relatively young. Donors under 30 years accounted for $64.41 \%$,
Tabe 1: Number of HIV cases confirmed at the National Blood Transfusion Center (CNTS) of Lomé from January 2008 to December 2012.

\begin{tabular}{|c|c|c|c|c|c|c|}
\hline \multirow[t]{2}{*}{ Years } & $\begin{array}{c}\text { Number } \\
\text { of } \\
\text { donors }\end{array}$ & \multicolumn{4}{|c|}{ Sex } & $\begin{array}{l}\text { HIV } \\
\text { cases } \\
\text { confir- } \\
\text { med }\end{array}$ \\
\hline & & Males & $\%$ & Females & $\%$ & \\
\hline 2008 & 1470 & 1117 & 75,98 & 353 & 24,02 & o \\
\hline 2009 & 2266 & 1733 & 76,48 & 533 & 23,52 & 5 \\
\hline 2010 & 2323 & 1765 & 75,98 & 558 & 24,02 & 5 \\
\hline 2011 & 3152 & 2427 & 76,99 & 725 & 23,01 & 3 \\
\hline 2012 & 6831 & 5690 & 83,30 & 1141 & 16,70 & 2 \\
\hline Total & 16042 & 12732 & 79,37 & 3310 & 20,63 & 15 \\
\hline
\end{tabular}

All confirmed cases of HIV seroconversion were HIV-1 positive.

Table 2: Evaluation of the incidence rate per 100 ooo personyears at the National Blood Transfusion Center (CNTS) of Lomé (Togo) from January 2008 to December 2012.

\begin{tabular}{lccc} 
Years & $\begin{array}{c}\text { Number } \\
\text { of person- } \\
\text { years }\end{array}$ & $\begin{array}{c}\text { Incident } \\
\text { cases }\end{array}$ & $\begin{array}{c}\text { Incidence rate for } \\
\mathbf{1 0 0} \text { ooo person- } \\
\text { years }\end{array}$ \\
\hline 2008 & 3290,51 & 0 & 00,00 \\
2009 & 5237,65 & 5 & 95,46 \\
2010 & 5828,32 & 5 & 85,79 \\
2011 & 7852,56 & 3 & 38,20 \\
2012 & 21957,15 & 2 & 09,11 \\
\hline
\end{tabular}

Table 3: Evaluation of HIV residual risk of transfusion at the National Blood Transfusion Center (CNTS) of Lomé (Togo) from January 2008 to December 2012.

\begin{tabular}{ccc} 
Year & $\begin{array}{c}\text { Residual risk (for } \\
\mathbf{1 0 0 0 0 0} \text { donations) }\end{array}$ & $\begin{array}{c}\text { Residual risk } \\
\text { (for } \mathbf{1} \text { donation) }\end{array}$ \\
\hline 2008 & 0 & 0 \\
2009 & 5,75 & $1 / 17391$ \\
2010 & 5,17 & $1 / 19342$ \\
2011 & 2,30 & $1 / 43478$ \\
2012 & 0,55 & $1 / 181818$ \\
\hline
\end{tabular}

From 2009 to 2012 the RR decreased by 10.45 times. 
while the donors over 50 years old accounted for only $3.73 \%$. This corroborates the observation of FETEKE et al. in 2006 in CNTS of Lomé who found that $72.6 \%$ of donors were between 18 to 29 years [7]. On the other hand, Traore in 2006 in Quebec had found an older population of donors with only $16.41 \%$ of donors under 30 years and more $36.57 \%$ of donors over 50 years [8]. The male was strongly represented in our study with $79.37 \%$ of men for $20.63 \%$ of women. In 2002, LOUA et al. had also found a high proportion of male regular donors (87.3\%) in Conakry, Guinea [9].

In our study students, apprentices and students accounted for more than half of the donors or $55.82 \%$ and employees in the private and public sectors, the proportion of $40.53 \%$. This predominance of young donors (students, apprentices, students) could be explained by the fact that the university campus site is less than $1 \mathrm{~km}$ from the site of CNTS and that regular briefings of IEC (Information Education Communication) and mobile collection are organized for students and pupils.

After this study, no cases of HIV have been confirmed in 2008. This can be explained by the fact that the confirmation of HIV positive detected cases had started only in 2008 and blood donors should make themselves the moving to INH for confirmation of the results of CNTS. That could discourage donors without high financial resources reducing opportunities for confirmation of HIV. In 2009, the RR was $1 / 17391$ donations. The risk of HIV transmission was lower than that of Ghana in 2001 [10], Côte d'Ivoire in 2002-2004 [11] which were 1/260 and $1 / 5780$ donations respectively. It was, by against higher than that in Dakar in Senegal, which was 1/28571 donations in 2005 [12]. In Western countries, the RR was relatively lower than that of Lomé. It was of $1 / 117370$ in Canada in 2000 [13]. In 2002, it was of $1 / 1400000$ in France [14], of 1/2300oo in Germany [15] and 1/102249 in Spain [16]. In United Kingdoms, it was of $1 / 469484$ [17].

In 2012, the RR was ten times lower than that in 2009. This can be explained by the fact that there is a national policy and good practice guide for blood transfusion in Togo that implementation has already started and continues acceptably. The CNTS of Lomé also had received in 2008 the project to support blood safety and the fight against HIV / AIDS financed by AFD (French Development Agency). This project helped to improve the biological qualification of donation by automating laboratory tests, awareness and training staff on donor screening procedures and of blood donations. The promotion of blood donation based on the principle of self-exclusion and donor awareness on measures of prevention of infections transmitted through blood, established at CNTS of Lomé during medical examination of donors and campaigns for blood donation for the population also played a large role in decreasing the RR.

The CNTS of Lomé could improve the current level of transfusion safety if resources permit it, by including in its future prospects, the introduction of pathogen inactivation during the preparation of the blood products. The technique of Intercept ${ }^{\circledR}$ would be a great benefit because it is effective against naked envelop viruses, intra and extracellular, bacteria and parasites including Plasmodium falciparum [18] which is responsible for malaria in Togo. The applicability of this technique to concentrated red cells is being researched.

\section{CONCLUSION}

This study shows a real decrease of residual risk (RR) 2008 to 2012 in CNTS of Lomé. Further efforts are still needed to improve blood safety in Togo and allow constant reduction of HIV residual risk. To do this, the CNTS of Lomé must implement effective strategies for donor retention to maintain and improve transfusion safety. Regular evaluation of the viral residual risk by blood transfusion every three years at least must also be done.

\section{Author Contributions}

Liza Koboyo Nadjir - Substantial contributions to conception and design, Acquisition of data, Analysis and interpretation of data, Drafting the article, Revising it critically for important intellectual content, Final approval of the version to be published

Akuété Yvon Segbena - Analysis and interpretation of data, Revising it critically for important intellectual content, Final approval of the version to be published Jean-Pierre Cazenave - Analysis and interpretation of data, Revising it critically for important intellectual content, Final approval of the version to be published

\section{Guarantor}

The corresponding author is the guarantor of submission.

\section{Conflict of Interest}

Authors declare no conflict of interest.

\section{Copyright}

(C) 2015 Liza Koboyo Nadjir et al. This article is distributed under the terms of Creative Commons Attribution License which permits unrestricted use, distribution and reproduction in any medium provided the original author(s) and original publisher are properly credited. Please see the copyright policy on the journal website for more information.

\section{REFERENCES}

1. World Health Organization. Global data on blood safety and blood donation. Fact sheet $\mathrm{N}^{\circ} 279$. June 2007. [Available at: http://www.who.int/ mediacentre/factsheets/fs279/en/] 
2. Schreiber GB, Busch MP, Kleinman SH, Korelitz JJ. The risk of transfusion-transmitted viral infections. The Retrovirus Epidemiology Donor Study. N Engl J Med 1996 Jun 27;334(26):1685-90.

3. Situation de l'épidémie du SIDA au Togo. [Available at: www.cnlstogo.org/index.php?option.id.togo.2012.]

4. Touré-Fall AO, Dièye TN, Sall A, et al. Residual risk of transmission of HIV and HBV, in Senegalese national blood bank from 2003 to 2005.

[Article in French]. Transfus Clin Biol 2009 NovDec;16(5-6):439-43.

5. Dagnra AY, Prince-David M, Agbenu S, Ouro-Akpo $\mathrm{T}$, Hounkpati F. Prévalence et risque de transmission du VHC après dépistage des VIH et VHB chez les donneurs de sang. Médecine et Maladies Infectieuses 2002;32(6):315-6.

6. Busch MP, Lee LL, Satten GA, et al. Time course of detection of viral and serologic markers preceding human immunodeficiency virus type 1 seroconversion: implications for screening of blood and tissue donors. Transfusion 1995 Feb;35(2):91-7.

7. Fétéké L, Mawussi K, Lakté P, Kuéviakoe IM, Haudrechy D, Ségbéna AY. Internal quality control of the blood products in the Lomé National Blood Transfusion Centre.

[Article in French]. Tunis Med 2008 Jul;86(7):698703.

8. Traoré AN. Mesure de l'incidence de l'hépatite virale B selon la séroconversion pour l'Ac $\mathrm{HBc}$ chez les donneurs de sang du Québec (mémoire de maîtrise en science). Univer. de Laval, octobre 2006. [Available at: www.theses.ulaval.ca/2006/24027/24027.pdf]

9. Loua A, Sow EM, Magassouba FB, Camara M, Baldé MA. Evaluation of residual infectious risk among blood donors in National Center of Blood Transfusion in Conakry.

[Article in French]. Transfus Clin Biol 2004 Apr;11(2):98-100.

10. Candotti D, Sarkodie F, Allain JP. Residual risk of transfusion in Ghana. Br J Haematol 2001 Apr;113(1):37-9.

11. Ouattara H, Siransy-Bogui L, Fretz C, et al. Residual risk of HIV, HVB and HCV transmission by blood transfusion between 2002 and 2004 at the Abidjan National Blood Transfusion Center. Transfus Clin Biol 2006 Oct;13(4):242-5.

12. Glynn SA, Kleinman SH, Wright DJ, Busch MP; NHLBI Retrovirus Epidemiology Donor Study. International application of the incidence rate/window period model. Transfusion 2002 Aug;42(8):966-72.

13. Chiavetta JA, Escobar M, Newman A, et al. Incidence and estimated rates of residual risk for HIV, hepatitis $\mathrm{C}$, hepatitis B and human T-cell lymphotropic viruses in blood donors in Canada, 1990-2000. CMAJ 2003 Oct 14;169(8):767-73.

14. Pillonel J, Laperche S; Groupe “Agents Transmissibles par Transfusion” de la Société française de transfusion sanguine; Etablissement français du sang; Centre de transfusion sanguine des armées. Trends in residual risk of transfusion-transmitted viral infections (HIV, HCV, HBV) in France between 1992 and 2002 and impact of viral genome screening (Nucleic Acid Testing).

[Article in French]. Transfus Clin Biol 2004 Apr;11(2):81-6.
15. Institut de veille sanitaire, Institut national de transfusion sanguine, Etablissement français de sang, Service de santé des armées. Surveillance épidémiologique des donneurs de sang 19922007. [Available at: http://www.invs.sante.fr/ publications/2008/donneurs_sang_1992_2007/ index.html]

16. Alvarez do Barrio M, González Díez R, Hernández Sánchez JM, Oyonarte Gómez S. Residual risk of transfusion-transmitted viral infections in Spain, 1997-2002, and impact of nucleic acid testing. Euro Surveill 2005 Feb;10(2):20-2.

17. Soldan K, Davison K, Dow B. Estimates of the frequency of HBV, HCV, and HIV infectious donations entering the blood supply in the United Kingdom, 1996 to 2003. Euro Surveill 2005 Feb;10(2):17-9.

18. Cazenave JP. Universal implementation of pathogen inactivation in labile blood products is a major step towards transfusion safety.

[Article in French]. Bull Acad Natl Med 2010 Dec;194(9):1707-19; discussion 1719-20. 
Access full text article on other devices

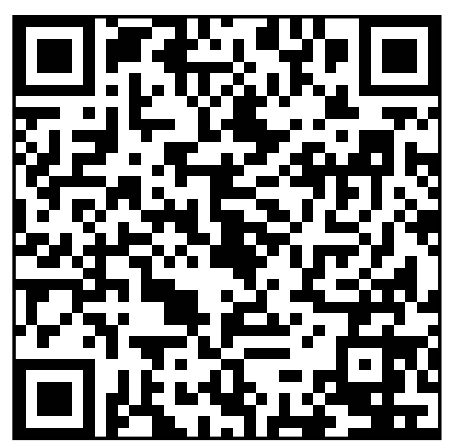

Access PDF of article on other devices

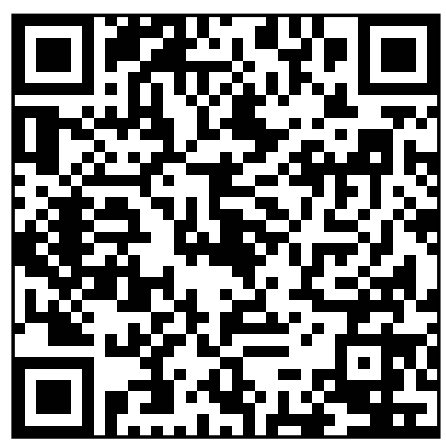

